\title{
Alterations in Urinary Microalbumin and Serum Antioxidants in Sickle Cell Disease
}

\author{
${ }^{1}$ PK Patra, ${ }^{2}$ PK Khodiar, ${ }^{3} \mathrm{D}$ Sahu, ${ }^{4}$ GK Sahu
}

\begin{abstract}
Changes in the level of various biochemical parameters play a significant role in the physiopathology of sickle cell disease (SCD). The aim of this study is to determine the level of urinary micoalbumin and plasma level of ascorbic acid and uric acid in subjects suffering from sickle cell anemia. A total of 30 subjects consisting of both males and females whose age range varied from 10 to 30 years were included in the study. The urinary albumin/creatinine ratio invariably increased in all studied subjects as compared with the control subjects. The level of ascorbic acid in the plasma significantly declined in SCD subjects when compared with that of control subjects $(p<0.05)$. Also, the decrease in level of uric acid in plasma of SCD patients was significant as compared with the control subjects. Significant changes in these biochemical parameters thus could be used as reliable markers in nephropathy in sickle cell patients and thus in the management of the disease.
\end{abstract}

Keywords: Ascorbic acid, Microalbuminuria, Nephropathy, Sickle cell disease.

How to cite this article: Patra PK, Khodiar PK, Sahu D, Sahu GK. Alterations in Urinary Microalbumin and Serum Antioxidants in Sickle Cell Disease. Indian J Med Biochem 2016;20(1):1-5.

Source of support: Nil

Conflict of interest: None

\section{INTRODUCTION}

Sickle cell disease (SCD) is one of the most common genetic disorders worldwide. The disease is caused by a single base pair deoxyribonucleic acid (DNA) mutation encoding the $\beta$-globin molecule, resulting in substitution of valine for glutamic acid at the sixth position of $\beta$-globin chain. Sickle cell disease is characterized by chronic hemolysis with frequent vaso-occlusive crises. Biochemical abnormalities of various types have been associated with SCD. ${ }^{1}$ Alteration in blood as well as urinary parameters could act as indicators in the management of the disease. Kidney is particularly susceptible to sickling of red cells and hypoxic damage because of the hypertonic and acidic environment

\footnotetext{
${ }^{1}$ Director Professor , ${ }^{2,4}$ Associate Professor, ${ }^{3}$ Student

${ }^{1-4}$ Department of Biochemistry, Pt. Jawahar Lal Nehru Memorial Medical College, Raipur, Chhattisgarh, India

Corresponding Author: GK Sahu, Associate Professor Department of Biochemistry, Pt. Jawahar Lal Nehru Memorial Medical College, Raipur, Chhattisgarh, India, Phone: +919826173912, e-mail: sahugk234@gmail.com
}

of renal medulla. ${ }^{2}$ Studies in pediatric patients had revealed that renal damage starts during childhood and continues throughout life. Prolonged glomerular hyperfiltration in SCD during childhood and early adult years leads to glomerular injury, resulting in glomerular sclerosis, proteinuria, and progressive renal failure. ${ }^{3}$ Microalbuminuria is an early manifestation of sickle cell-related renal disease and is considered to be a risk factor for developing renal impairment in future. ${ }^{4,5}$ It has been reported that adult SCD patients with severe anemia have glomerular injury and proteinuria. ${ }^{6}$ A study in pediatric patients with SCD found that proteinuria was significantly associated with lower hemoglobin $(\mathrm{Hb})$ concentration, higher mean corpuscular volume, and higher leukocyte count. ${ }^{7}$ The incidence of proteinuria increases with advancing age. As proteinuria in the early stages of nephropathy is a hallmark of future deterioration of renal function, it is important to detect this early with routine surveillance. Intervention at this stage may prevent or at least delay the renal damage.

Likewise, changes in the plasma level of vitamin antioxidants like vitamins $\mathrm{A}, \mathrm{C}$, and $\mathrm{E}$ have been noticed in sickle cell patients. Decrease in the level of these antioxidants in SCD patients could cause oxidative stress. The depletion in the levels of these antioxidants may account for some of the observed manifestations of SCA, such as increased susceptibility to infection and hemolysis. ${ }^{8}$ Ascorbic acid could contribute to reduction of the increased oxygen free radicals generated in sickle red blood cells (RBC) and to the recycling of vitamin E in the cells, while renal loss could contribute to the low plasma levels. The compound is known to protect RBC against hydrogen peroxide-induced hemolysis. Also, it had a significant stimulatory effect on the rate of glucose oxidation by the pentose phosphate shunt, especially in the sickle RBC. Another parameter, uric acid, has been known to be associated with the pathophysiology of vascular occlusion in sickle cell anemia. ${ }^{9}$ Studies have revealed the elevation of uric acid in sickle cell patients compared with normal control groups. ${ }^{10}$ Higher concentration of urate is found to possess antisickling activity on sickle cell erythrocytes and is beneficial to sickle cell patients in a compensatory way. ${ }^{11}$

The prevalence of sickle cell anemia is approximately 10 to $12 \%$ in the population of Chhattisgarh. ${ }^{12}$ Therefore, in the present study, an attempt has been made to determine some biochemical parameters, such as microalbumins and 
creatinine in urine and creatinine, ascorbic acid, and uric acid in blood of subjects suffering from SCD that could be used as indicators of early-stage kidney damage sickle cell patients.

\section{MATERIALS AND METHODS}

\section{Place of Study and Characteristics of Subjects}

The present study was carried out in the Department of Biochemistry, Pt. Jawahar Lal Nehru Memorial Medical College, Raipur, Chhattisgarh, and was approved by the ethical committee. Those subjects diagnosed with SCD and hospitalized for sickle cell crisis in the pediatrics and medicine ward of the college were considered for the study. A total of 30 subjects consisting of 21 males and 9 females participated in the study. The patients belonged to the age group of 10 to 30 years. All patients were diagnosed by solubility test followed by cellulose acetate electrophoresis, the standard test usually followed for the diagnosis of SCD. Only those patients who were homozygous to the SCD (SS) were included in the study. Equal number of age- and gender-matched subjects that were tested negative for SCD were taken as controls. The clinical and other details of the subjects were collected through structured questionnaire.

\section{Measurement of Physical Parameters}

The height and weight of each participant were measured. The body mass index (BMI) was calculated using the formula weight in $\mathrm{kg} /$ height in $\mathrm{m}^{2}$. Blood pressure of the participants was also measured during the health check-up.

\section{Collection and Processing of Samples}

About $3.5 \mathrm{~mL}$ of blood samples was collected from each subject, both control and sickle patients by vein puncture; $1.0 \mathrm{~mL}$ of the blood was transferred into ethylenediaminetetraacetic acid (EDTA) vials and was used for the determination of $\mathrm{Hb}$ content of the subjects. Remaining blood sample was allowed to clot in plain vial and then spun in a centrifuge at $2000 \mathrm{rpm}$ for 5 minutes. The supernatant serum was transferred into a fresh Eppendorf vial; 20 to $30 \mathrm{~mL}$ of fresh, midstream morning urine samples were collected in sterilized urine sample container. Serum ascorbic acid, uric acid, creatinine, as well as urine microalbumin and creatinine concentration were estimated on the same day. Whenever it was not possible, the samples were stored at $-80^{\circ} \mathrm{C}$ till further analysis.

\section{Determination of $\mathrm{Hb}$}

Hemoglobin was measured using automated threepart hematology cell counter (Mindray, BC-3000Plus, Shenzhen, P. R. China).

\section{Determination of Albumin and Creatinine}

The urine microalbumin content was determined by nephelometer method, by fully automated nephelometer (Beckman Coulter, Image-800, CA, USA) using kits of Beckman Coulter. Both urine and serum creatinine were determined by modified Jaffe's method using the kits of Randox.

\section{Measurement of Ascorbate and Uric Acid Content in Serum}

Plasma levels of ascorbic acid and uric acid were measured by reversed-phase high-performance liquid chromatography (HPLC; Young Lin Instruments, Acme 9000, Anyang, South Korea). The separation of the compounds was achieved by C18 column. The mobile phase used was $100 \%$ methanol (HPLC grade) and the solvent conditions were maintained at 2 to $98 \%$ methanol. Ascorbic acid and uric acid eluted from the column were detected at 245 and $293 \mathrm{~nm}$ respectively; $20 \mu \mathrm{L}$ sample volume was injected into HPLC by Hamilton $100 \mu \mathrm{L}$ syringe. The retention time for both ascorbic acid and uric acid was recorded. A standard graph was obtained each for ascorbic acid and uric acid.

\section{Statistical Methods}

All the results were analyzed using Student's t-test and Statistical Package for the Social Sciences (SPSS)-13 software. The standard deviation (SD) was calculated using MS Excel and the data were presented as mean of three independent measurements \pm SD.

\section{RESULTS}

\section{Physical Parameters}

The sample characteristics and other physical parameters of the subjects under study including height, weight, BMI, and blood pressure are presented in Table 1.

\section{Biochemical Parameters}

\section{Hemoglobin Content}

The $\mathrm{Hb}$ level of the patients varied within the range of 5.5 to $9.2 \mathrm{~g} / \mathrm{dL}$ in SS subjects, whereas in control subjects, the range was 12.0 to $16.0 \mathrm{~g} / \mathrm{dL}$. The mean $\mathrm{Hb}$ content of SS subjects was $7.3 \pm 0.95 \mathrm{~g} / \mathrm{dL}$ as compared with $13.26( \pm 2.01)$ $\mathrm{g} / \mathrm{dL}$ in control groups. The difference in the levels between cases and controls was statistically significant $(\mathrm{p}<0.05)$.

\section{Microalbumin and Creatinine Content}

In the present study, the mean urinary microalbumin concentration in homozygous SCD subjects was found 
Alterations in Urinary Microalbumin and Serum Antioxidants in Sickle Cell Disease

Table 1: Sample characteristic of subjects

\begin{tabular}{llllll}
\hline \multirow{2}{*}{ Variables } & \multicolumn{2}{c}{$S S(n=30)$} & & \multicolumn{2}{c}{ Control $(n=30)$} \\
\cline { 2 - 3 } \cline { 5 - 6 } & Mean $\pm S D$ & Range & & Mean $\pm S D$ & $10-30$ \\
Age $($ years $)$ & $12.4( \pm 2.3)$ & $10-30$ & & $15.7( \pm 3.1)$ & $108-170$ \\
Height $(\mathrm{cm})$ & $108( \pm 3.8)$ & $102-168$ & & $115( \pm 2.7)$ & $32-57$ \\
Weight $(\mathrm{kg})$ & $32.52( \pm 5.2)$ & $25-52$ & & $39.52( \pm 4.4)$ & $120 / 80-130 / 90$ \\
Blood pressure $(\mathrm{mm} \mathrm{Hg})$ & $115( \pm 5.5) / 79( \pm 3.1)$ & $115 / 70-130 / 90$ & & $118( \pm 4.35) / 78( \pm 3.6)$ & $17-22$ \\
$\mathrm{BMl}\left(\mathrm{kg} / \mathrm{m}^{2}\right)$ & $16.27( \pm 4.25)$ & $15-18$ & & $18.27( \pm 3.21)$ & $12-16$ \\
$\mathrm{Hb}(\mathrm{g} / \mathrm{dL})$ & $7.3( \pm 0.95)$ & $6.5-9.2$ & & $13.26( \pm 2.01)$ & \\
\hline
\end{tabular}

Mean values $( \pm \mathrm{SD})$ are presented

Table 2: Level of biochemical parameters measured in SS and control subjects

\begin{tabular}{|c|c|c|c|}
\hline & $S S(n=30)$ & Control $(n=30)$ & \\
\hline Parameters & Mean $\pm S D$ & Mean $\pm S D$ & $p$-value \\
\hline U. albumin/creatinine ratio $(\mathrm{mg} / \mathrm{g})$ & $52.16^{*} \pm 3.021$ & $14.23 \pm 1.032$ & $<0.05$ \\
\hline S. creatinine $(\mathrm{mg} / \mathrm{dL})$ & $0.823 \pm 0.391$ & $0.671 \pm 0.124$ & - \\
\hline S. ascorbic acid (mg\%) & $0.416^{*} \pm 0.551$ & $1.345 \pm 0.132$ & $<0.05$ \\
\hline S. uric acid $(\mathrm{mg} \%)$ & $8.4^{*} \pm 1.163$ & $4.798 \pm 0.689$ & $<0.05$ \\
\hline B. $\mathrm{Hb}(\mathrm{g} / \mathrm{dL})$ & $7.3^{*} \pm 0.95$ & $13.26 \pm 2.01$ & $<0.05$ \\
\hline
\end{tabular}

*Significance of difference at $p<0.05$ level by Student's t-test when compared with controls

to be $16.16 \pm 0.867 \mu \mathrm{g} / \mathrm{mL}$, while in normal, age- and sex-matched controls, it was $3.93 \pm 0.179 \mu \mathrm{g} / \mathrm{mL}$. The difference in the levels between cases and controls was statistically significant $(\mathrm{p}<0.05)$. Urine creatinine in homozygous SCD was $0.3 \pm 0.029 \mathrm{~g} / \mathrm{dL}$ and in controls was found to be $0.26 \pm 0.032 \mathrm{~g} / \mathrm{dL}$.

The serum creatinine concentration was observed to be $0.823 \pm 0.391$ and $0.671 \pm 0.124 \mathrm{mg} / \mathrm{dL}$ in SS and control subjects respectively. Through there is an increase in serum creatinine in SS subjects compared with that of controls, the level remained in the normal range and was not significant.

The urinary albumin to creatinine ratio in SS and control subjects was found to be $52.16 \pm 3.021$ and $14.23 \pm 1.032$ respectively. The difference in the levels between cases and controls was statistically significant $(\mathrm{p}<0.05)$.

\section{Ascorbic Acid Content}

The mean serum level of ascorbic acid in homozygous SCD subjects hospitalized for sickle cell crisis was measured to be $0.416 \pm 0.551 \mathrm{mg} \%$, while in normal, age- and sex-matched healthy controls, the content was $1.345 \pm 0.132 \mathrm{mg} \%$. The difference in the levels between cases and controls was statistically significant $(\mathrm{p}<0.05)$.

\section{Uric Acid Content}

The mean serum level of uric acid in homozygous SCD patients hospitalized for sickle cell crisis was measured to be $8.4 \pm 1.163 \mathrm{mg} \%$, while in normal, age- and sex-matched healthy controls, it was $4.798 \pm 0.689 \mathrm{mg} \%$. The difference in the levels between cases and controls was statistically significant $(p<0.05)$.

The level of the biochemical parameters in SS and control subjects is presented in Table 2 .

\section{DISCUSSION}

Alteration in physical and biochemical parameters is an indicator of the susceptibility to various diseases and could be used as early markers. Sickle cell pathophysiology comprises a complex interplay of episodic vaso-occlusive events, ischemic-reperfusion injury, overproduction of reactive oxygen species, inflammation, endothelial activation, and hemolysis. The hemolysis and oxidative stress act synergistically to promote vascular dysfunction in SCD. Various complications of SCD result from abnormal shape (sickling) and deformability of RBC causing obstruction in the microvasculature of different organs and premature destruction of red cells. Subsequent acute and chronic tissue ischemia lead to progressive organ damage. ${ }^{13}$ In the present study, the reduction in height, body weight, and $\mathrm{Hb}$ level of SS subjects was found to be significantly reduced compared with control groups (Tables 1 and 2). The urine albumin/creatinine ratio of SCD subjects hospitalized for sickle cell crisis was found to be significantly more than that of normal, ageand sex-matched healthy control subjects. The difference in the levels between cases and controls was statistically significant $(p<0.05)$. Urine albumin/creatinine ratio is a better marker of renal damage. Further, microalbuminuria is considered as an early manifestation of sickle cellrelated renal disease and could be a risk factor for developing renal impairment in future. ${ }^{4}$ The condition of 
microalbuminuria is not only a marker of renal disease but is also a predictor of disease progression. Routine screening of microalbuminuria may help to detect those at increased risk of renal disease. Chronic kidney disease prevalence is high among SCA patients with significant microalbuminuria. ${ }^{14}$ It has been studied that sickle cell glomerulopathy occurs in a majority of older adults with SS disease, and its prevalence is much higher than reported on the basis of a positive urinary dipstick for protein. ${ }^{15}$ Microalbuminuria has also been suggested as a simple biomarker for screening of early kidney injury in children with SCD. ${ }^{16}$ In our study, we have observed an elevated level of microalbumin in homozygous SCD patients hospitalized for sickle cell crisis (Table 2) compared with the normal, age- and sex-matched controls. Although the serum creatinine level increased in SS subjects compared with that of controls, it was not significant. The urine albumin/creatinine ratio increased significantly in SCD subjects compared with controls, indicates that this ratio is a better indicator than serum creatinine alone for early renal damage.

The role of oxidant damage to red cells in SCD has been of interest in recent years. Ascorbic acid is a wellknown antioxidant. In the present study, the mean blood level of ascorbic acid in SCD subjects hospitalized for sickle cell crisis was measured to be $0.416 \pm 0.132 \mathrm{mg} \%$, while in normal, age- and sex-matched healthy controls, it was $1.345 \pm 0.551 \mathrm{mg} \%$. The difference in the levels between cases and controls was statistically significant $(p<0.05)$. Low level of ascorbic acid in sickle cell patients has already been reported. ${ }^{17}$ It has also been observed that pretreatment of sickle cells with ascorbic acid protects their membranes against in vitro peroxidative lipid damage induced by their exposure to hydrogen peroxide. Thus, low serum ascorbic acid levels in sickle cell patients may be attributed to increased vulnerability of sickle cells to oxidant damage in vivo. The oxidative stress associated with sickle cell crisis might be a cause for induced renal damage leading to microalbuminuria. In a study, the effect of ascorbic acid supplementation (100 mg/day for 6 weeks) on blood pressure, packed cell volume, irreversibly sickled cells, percent fetal $\mathrm{Hb}$, $\mathrm{Hb}$ concentration, and erythrocyte osmotic fragility was assessed in children suffering from sickle cell anemia. Supplementation of ascorbic acid has been known to abolish the long tail of the erythrocyte osmotic fragiligram and also increases the resistance of the cells to lysis. ${ }^{18}$

Uric acid might have a role in influencing the pathophysiology of vascular occlusion in SCA. ${ }^{9}$ In the present study, the mean serum level of uric acid in homozygous SCD hospitalized for sickle cell crisis was measured to be significantly higher than that of control subjects. Uric acid acts as an antioxidant and also is known to have antisickling effect. Raised serum level of uric acids has also been noticed in children suffering from sickle cell anemia ${ }^{10}$ and thus could be used as a marker for early nephropathy.

Patients with sickle cell crisis with normal kidney function test, but having microalbuminuria and raised urinary albumin/creatinine ratio indicate the occurrence of imminent renal disease. So the measurement of microalbumin in urine might play a role in identifying the subsets of patients who are more likely to progress to renal manifestation in crisis events so that in time, preventive measures could be adopted as early as possible in the course of the disease.

\section{ACKNOWLEDGMENT}

Authors are thankful to the Dean, Pt. JNM. Medical College, for providing laboratory facility for carrying out this work.

\section{REFERENCES}

1. Pandey S, Sharma A, Dahia S, Shah V, Sharma V, Mishra RM, Pandey SW, Saxena R. Biochemical indicator of sickle cell disease: preliminary report from India. Indian J Clin Biochem 2012 Apr;27(2):191-195.

2. Ataga KI, Orringer EP. Renal abnormalities in sickle cell disease. Am J Hematol 2000 Apr;63(4):205-211.

3. Bourke E. The kidney in sickle cell disease. J Assoc Acad Minor Phys 1992;3(2):41-45.

4. Powars DR, Elliott-Mills DD, Chan L, Niland J, Hiti AL, Opas LM, Johnson C. Chronic renal failure in sickle cell disease: risk factors, clinical course and mortality. Ann Intern Med 1991 Oct;115(8):614-620.

5. Sasongko TH, Nagalla S, Ballas SK. Angiotensin converting enzyme (ACE) inhibitors for proteinuria and microalbuminuria in people with sickle cell disease. Cochrane Database Syst Rev 2013, Issue 3. Art. No.: CD009191. DOI: 10.1002/14651858. CD009191.

6. Faulkner M, Turner EA, Deus J, Phillips K, Weaver C, Taiwo O, Omitowoju O. Severe anaemia: a risk factor for glomerular injury in sickle cell disease. J Natl Med Assoc 1995 Mar;87(3):209-213.

7. Wigfall DR, Ware RE, Burchinal MR, Kinney TR. Prevalence and clinical correlates of glomerulopathy in children with sickle cell disease. J Pediatr 2000 Jun;136(6):749-753.

8. Essien EU. Plasma levels of retinol, ascorbic acid and alphatocopherol in sickle cell anaemia. Cent Afr J Med 1995 Feb;41(2):48-50.

9. Cerqueira BA, Boas WV, Zanette AD, Reis MG, Goncalves MS. Increased concentrations of IL-18 and uric acid in sickle cell anaemia: contribution of hemolysis, endothelial activation and the inflammasome. Cytokine 2011 Nov;56(2):471-476.

10. Al-Naama LM, Al-Sadoon TA. Levels of uric acid, urea and creatinine in Iraqi children with sickle cell disease. J Pak Med Assoc 2000 Mar;50(3):98-102.

11. Ekeke GI, Nduka N. The antisickling role of uric acid in sickle cell disease. Trop Geogr Med 1987 Apr;39(2):152-156. 
12. Patra PK, Chauhan VS, Khodiar PK, Dalla AR, Serjeant GR. Screening for the sickle cell gene in Chhattisgarh state, India: an approach to a major public health problem. J Community Genet 2011 Sep;2(3):147-151.

13. Aleem A. Proteinuria in adult Saudi patients with sickle cell disease is not associated with identifiable risk factors. Saudi J Kidney Dis Transpl 2010 Sep;21(5):903-908.

14. Abdu A, Emokpae MA, Uadia PO, Kuliya-Gwarzo A. Proteinuria among adult sickle cell anaemia patients in Nigeria. Ann Afr Med 2011 Jan-Mar;10(1):34-37.

15. Ferrone FA. Polymerization and sickle cell disease: a molecular view. Microcirculation 2004 Mar;11(2):115-128.
16. Becton LJ, Kalpatthi RV, Rackoff E, Disco D, Orak JK, Jackson SM, Shatat IF. Prevalence and clinical correlates of microalbuminuria in children with sickle cell disease. Pediatr Nephrol 2010 Aug;25(8):1505-1511.

17. Jain SK, Williams DM. Reduced levels of plasma ascorbic acid (vitamin C) in sickle cell disease patients: its possible role in the oxidant damage to sickle cells in vivo. Clin Chim Acta 1985 Jul;149(2-3):257-261.

18. Jaja SI, Ikotun AR, Gbenebitse S, Temiye EO. Blood pressure, hematologic and erythrocyte fragility changes in children suffering from sickle cell anaemia following ascorbic acid supplementation. J Trop Pediatr 2002 Dec;48(6):366-370. 